${ }^{1}$ Dr. Sc., Professor, Rector, State University of Infrastructure and Technologies, Kyiv, Ukraine ${ }^{2} \mathrm{PhD}$, Professor at the Department of Technical Systems and Control Processes in Navigation, State University of Infrastructure and Technologies, Kyiv, Ukraine ${ }^{3}$ Postgraduate student, State University of Infrastructure and Technologies, Kyiv, Ukraine

\title{
APPLICATION OF THE SYSTEM ANALYSIS OF IMPLEMENTATION OF THE INSTRUMENTAL METHOD OF NAVIGATION ON INLAND WATERWAYS OF UKRAINE
}

Context. The task of applying the scientific approach to the introduction of a modern navigation system on inland waterways of Ukraine is considered to solve, first of all, weakly structured problems characterized by the presence of an uncertainty factor and containing both formalized and unformulated elements that are not translated into the language of mathematics.

Objective - development of the methodology of system analysis at the stage of introduction of the instrumental method of navigation on inland waterways of Ukraine, which guarantees high quality of modeling in accordance with the exact criteria of navigation and economy.

Method. An approach to data processing is proposed, which is based on the study of the properties of the system with her further formalization. A model of the layout of the system based on electronic chart systems is developed, characterizing the fulfillment of the assigned tasks with an increased probability of safe navigation. The features of the state of the system using a mathematical model in the form of an undirected graph are considered. An algorithm for realizing the functional stability of the system is proposed. The results of the experiments make it possible to recommend the proposed method for introducing the instrumental method of navigation on inland waterways of Ukraine.

Results. The parameters of experimental research of the functioning of the stages of the functional stability of the coastal infrastructure and ship navigation equipment have been developed.

Conclusions. In the process of research a set of procedures that contain elements of scientific novelty are used and are aimed at formulating a problem situation, proposing a set of alternatives that are compared with performance criteria using the system stability factors.

Keywords: safety of navigation, electronic chart system, instrumental navigation method, algorithm, multiparametric optimization, graph, linguistic analysis, modeling.

\section{NOMENCLATURE}

$A=\left\{a_{\mathrm{i}}\right\}-$ a set of system elements;

$C_{\mathrm{c}}, C_{\mathrm{o}}, C_{\mathrm{B}}$ - complexity of the system: system, own, mutual;

$D$ - a set of elements of the system and the links between them;

$D_{\text {min }}-$ minimum distance to dangers;

$\operatorname{def}(p E-A)-$ power polynomial of Laplace variable $p$ of order $n$;

$E$ - deviation of the changed state of the system from the calculated one;

$F_{\text {в }}$ - function of system outputs;

$F \mathrm{c}-$ transition function of system state;

$f(x ; y)$ - function of position of vessel motion;

$F(x)$ - the component that determines the random nature of changes in system performance;

$h_{10}$ - zero depth at the first water measuring point;

$k_{1}, k_{2}$ - coefficients of motion and safety during its turning circle;

$M$ - mean-square error of vessel location;

$P_{\text {бп }}$ - probability of safe navigation of water transport;

$p$ - probability of events $\mathrm{x}$;

$(p E-A), S(p)$ - matrices: characteristical, adjoint;

$Q-$ a set of links between elements of the system;

$S(\varepsilon)$ - the area of infinitely small deviation during vessel motion;

$T_{t}$ - evolution operator;

$V$ - vector space $x_{0}, y_{0}$;

$V_{4}$ - actual length of the lock-chamber;
$V_{5}$ - dimensions of lock approach canal;

$V_{5-2}$ - radius of the turning circle

$V_{6}, V_{6-1}$ - the width of navigable channel under bridges and the height of a bridge above water;

$V_{7}$ - the smallest distance of the wires of electric power lines from the water level;

$v^{+(-)}, e^{+(-)}, f^{+(-)}$-increased (reduced) values $\{\mathrm{V}, \mathrm{E}$,

F of the constituent elements of the system;

$v$ - system memory parameter;

$X(t)$ - function of inputs of the system (control algorithm);

$x_{0}, y_{0}$ - display coordinates at calculated state of the system;

$\left(x_{0}^{1}, y_{0}^{1}\right)$ - display coordinates at changed state of the system;

$x_{i}$ - actual value of the adjustable parameter;

$\Delta x$ - inconsistency between $x_{\text {req }}$ i $x_{\mathrm{i}}$;

$X_{\text {req }}$ - required value of the adjustable parameter;;

$Y(t)$ - function of system outputs;

$y_{01 \text { вп }}-$ the value of water level at the first water measuring point;

$x, Y$-values on the scale from the domain $\mathrm{Y}$;

$a, b-$ any value in the plurality of linear admissible transformations, a $>0$;

$Z_{i m}$ - specific properties of the system element;

$Z_{i}$ - state of the system element;

$Z, Z(t)$ - state of the system;

$Z_{1}, Z_{2}$ - state of subsystems; 
$Z_{\text {сд }}$ - a set of admissible states of the system;

$\Delta_{3}-$ draft of the vessel;

$\Delta_{4-1}-$ margin of locks width $V_{4-1}$;

$\Delta_{6}, \Delta_{6-1}-$ maximum deviation of motion under bridges and height margin;

$\Delta_{7}$ - Minimum margin at the height of wires of power lines;

$\delta y_{01 \text { вп }}-$ deviation from zero depth at the first water measuring point;

$\Omega$ - vessel motion.

\section{INTRODUCTION}

In this century, river transport becomes one of the most important elements of transportation, and its development is a powerful catalyst for economic growth and increase of the state's defense capability. An effective mechanism of operation of water vehicles in the current conditions of intellectualizing decision-making system is the transition to an navigation instrumental procedure instead of existing pilot method and further improving of motion safety of water transport on inland waterways.

Particularly noteworthy are the most important applicative results of the proposed method, such as the possibility of automated display of an individual navigable lane for the vessel, depending on the chosen draft and the actual water level, and in the future, the refusal of installing coastal and floating structures of navigation equipment and the refusal of pilot principle of ship navigation.

The system of providing the navigation instrumental procedure is a coherent practice for collecting, integrating, exchanging, presenting and analyzing information on vessels and coastal services by means of information technologies to increase the safety of navigation and environmental protection on inland waterways of Ukraine. This is a system for the integrated use of information that provides and maintains electronic cartographic means of navigation [1]. Thus, there is combining of information from numerous sources to find more accurate and reliable data about the situation than the results obtained from these sources separately. In addition, it should be noted that the introduction of navigation instrumental procedure will allow to shut down the ship navigation on the fairway channels in particular periods and follow only selected vessels quickly.

In this case, system analysis is used to solve, firstly, semistructured problems of implementing the system of providing the navigation instrumental procedure, namely problems, the composition of the elements and relationships of which are only partially established; the problems appear, as a rule, in situations that are characterized by the presence of an uncertainty factor and contain both formalized and non-formalized elements that are not translated into the language of mathematics. There are no universal methods and methods for system analysis. What is common to all methods of system analysis is determining the regularities of system operation, opting for system structure and choosing the best option by solving the problems of decomposition, analysis and synthesis of the system under investigation.
The system implementation of providing the navigation instrumental procedure is considered as a system object, taking into account its consistent nature, that is, not as a whole, but as a complex of interconnected constituent elements, their properties and processes. Besides this, system analysis is the most constructive of the directions of system researches, which involves methods and models of theory of systems for their practical application.

The aim of this work is to develop a method of system analysis at the stage of system implementation of providing navigation instrumental procedure on inland waterways of Ukraine, which guarantees high-quality modeling in accordance with precise navigation criteria.

\section{PROBLEM STATEMENT}

In order to end of purpose, it is necessary to consistently solve a number of tasks related to the implementation of divided information and telecommunication system. The most important step in solving the problems is to develop a method of system analysis.

Let suppose that we have an initial sample of setting the problem of system analysis of the current pilot navigation method, which is as follows: $A=\left\{a_{k}\right\}, Z_{\mathrm{i}}=\left\{z_{k n}\right\}, Q=\left\{q_{k n}\right\}$, $D=\{A, Q\}$. This does not correspond to the regularities of the operation of a complex object with the current navigation instrumental procedure through existing local, sectoral tasks and principles of ensuring its life cycle. The solution of the problem is to determine complex problems of the system object and processes, which differ from a simple sum of properties of elements with the same type of multilevel communications.

Initial sampling for system analysis for providing the navigation instrumental procedure has the following form: $A=\left\{a_{\mathrm{i}}\right\}, Z_{\mathrm{i}}=\left\{z_{i j}\right\}, Q=\left\{q_{i j}\right\}, D=\{A, Q\}, k \neq i, j \neq m$, $Z\left(t_{1}\right) \rightarrow Z\left(t_{2}\right) \rightarrow Z\left(t_{3}\right) \ldots, Z(t)=F \mathrm{c}[X(t)]$.

It is necessary to solve the problem of system operation in a continuous mode $f\left(x_{0}-0\right)=f\left(x_{0}+0\right)=f\left(x_{0}\right), \forall x \in R$ and taking into account the signs of dynamic system $x(t)=T_{t}$ $x\left(t_{0}\right)$ in the conditions of significant uncertainty and the impact of the environment on it.

The evaluation method of task solving for functioning of navigation instrumental procedure with a continuous output is criteria method; according to this method, each individual alternative is estimated by a specific number (criterion, target function). Comparison of alternatives is reduced to comparison of corresponding numbers, that is, for the entire set of alternatives $X=\left\{x_{n}\right\}$, the target function $Z=f(x) \Rightarrow \max$ or min is introduced. The values of $Z_{\text {min }}<Z<Z_{\max }$ alternatives are expressed in terms of scalar, vector, and plural quantities. The main type of scales is the scale of intervals, since this type contains scales that are accurate to the set of positive linear admissible transformations of the form $f(x)=a x+b$ :

$$
\frac{x_{1}-x_{2}}{x_{3}-x_{4}}=\frac{f\left(x_{1}\right)-f\left(x_{2}\right)}{f\left(x_{3}\right)-f\left(x_{4}\right)}=\text { const. }
$$

\section{LITERATURE REVIEW}

It happened that the problem of the instrumental procedure support system use on the inland waterways of 
Ukraine, which is being investigated, has not been fully studied yet, some of its issues are investigated superficially and fleetingly. As the analysis showed, a scientifically grounded approach of this direction was considered only in the form of hypotheses without theoretical substantiation.

When applying the functional stability of the instrumental procedure support system, which is considered in this article, various variants of the concept of stability are taken into account-Lyapunov stability, stability in probability, Lagrange stability, etc. However, this concept refers not to this object, but only to one of its properties. There are plenty of methods for analyzing stability developed for different systems: methods of Lyapunov, Hurwitz, Mykhailov, Popov, and others. In the classical theory of stability, the criteria for determining the stability of the system are developed $[6,7]$.

The concept of functional stability for a dynamic system was first defined in works of professor O. A. Mashkov [2]. The theory of developing of stable distributed automated control systems is proposed by professor O. V. Barabash. [3]. This theory is based on the estimation of the connectivity of the graphs of network. The proposed approach is used in the study of the state of the system using a mathematical model in the form of a non-oriented graph, which allowed to consider the features of system safety and develop an algorithm for implementing its functional stability.

There are also other approaches to providing functional stability for special purpose navigation system (Professor Yu. V. Kravchenko) [11]. It should be noted that this classical approach to the theory of stability for modern systems, based on the active use of methods of artificial intelligence, does not meet the requirements concerning adequacy and reliability of estimation of stability of such systems' operation. Due to this, the dependence of the models and methods of the theory of functional stability on the domain of their application is taken into account in the system analysis.

Besides this, the imperfection of regulatory standards allowed the designer to independently develop and implement algorithms of implementing of functional capability of electronic and cartographic equipment. As the linguistic analysis showed, this resulted in significant differences in the design of information and control panels, various sublevels of the menu, formats of vector electronic map display. According to the data set out in the UNECE Resolutions, in addition to the mandatory requirements for the equipment of river electronic cartographic systems ("must be"), there are some which are not obligatory ("may be") without a specific indication of minimum requirements for displaying such information, which greatly complicated the operation of various types of systems and conducting system analysis.

The problem connected with the system of providing the navigation instrumental procedure also calls into question the need of detailed depth mapping on electronic river maps, since the precise indication of the position of a fairway channel is much more important for navigation safety. The publications about the update of the displayed depth in the system electronic map of rivers with the navigation instrumental procedure did not solve the problem and the same problem was considered only at the level of suggestions and hypotheses.
In scientific works of L. L. Vahushchenko "Ship navigation and information systems", "Modern information technologies in navigation" $[1,4]$, D. A. Haharskyi "Electronic cartographic systems in modern navigation" [5], the problem of using the detailed array of depth with the navigation instrumental procedure consisted only in taking into account the corrections using the cartographic editor of the river electronic mapping system that is, manually without a systematic scientifically grounded approach to the periodicity of updating the existing depths on the river electronic map, its automation and display.

An important problem is the choice of structure to represent the system of providing the navigation instrumental procedure, taking into account its features and capabilities. On the basis of the comparative analysis of structures of system theory proposed by academicians $\mathrm{P}$. K. Anokhin, L von Bertalanfi, A. A. Bohdanov [6, 7], information estimates of the degree of wholeness and the coefficient of use of system components, which are interpreted as estimates of stability in making structural elements freeness are used.

\section{MATERIALS AND METHODS}

First, consider the circular diagram of the stages of increasing the efficiency of water vehicles operation on inland waterways in Ukraine (Fig. 1).

From the circular scheme it follows that the increase of efficiency of operation of water transport on inland waterways of Ukraine is consistent. The system of providing the navigation method is considered to be a set of objects having integral properties and regularities, as well as a set of connectivities between objects and their properties.

Fig. 2 shows the key components of the navigation instrumental procedure on inland waterways in Ukraine. According to this:

- the operation of navigation equipment and equipment of the coastal infrastructure belongs to the divided hierarchical intellectualized system of management of a complex technical object;

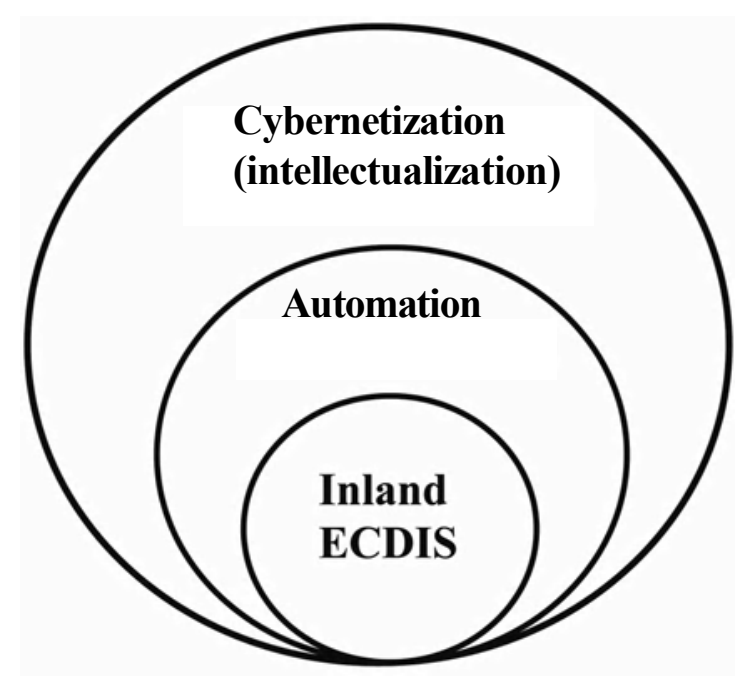

Figure 1 - The stages of increasing the efficiency of water transport exploitation 


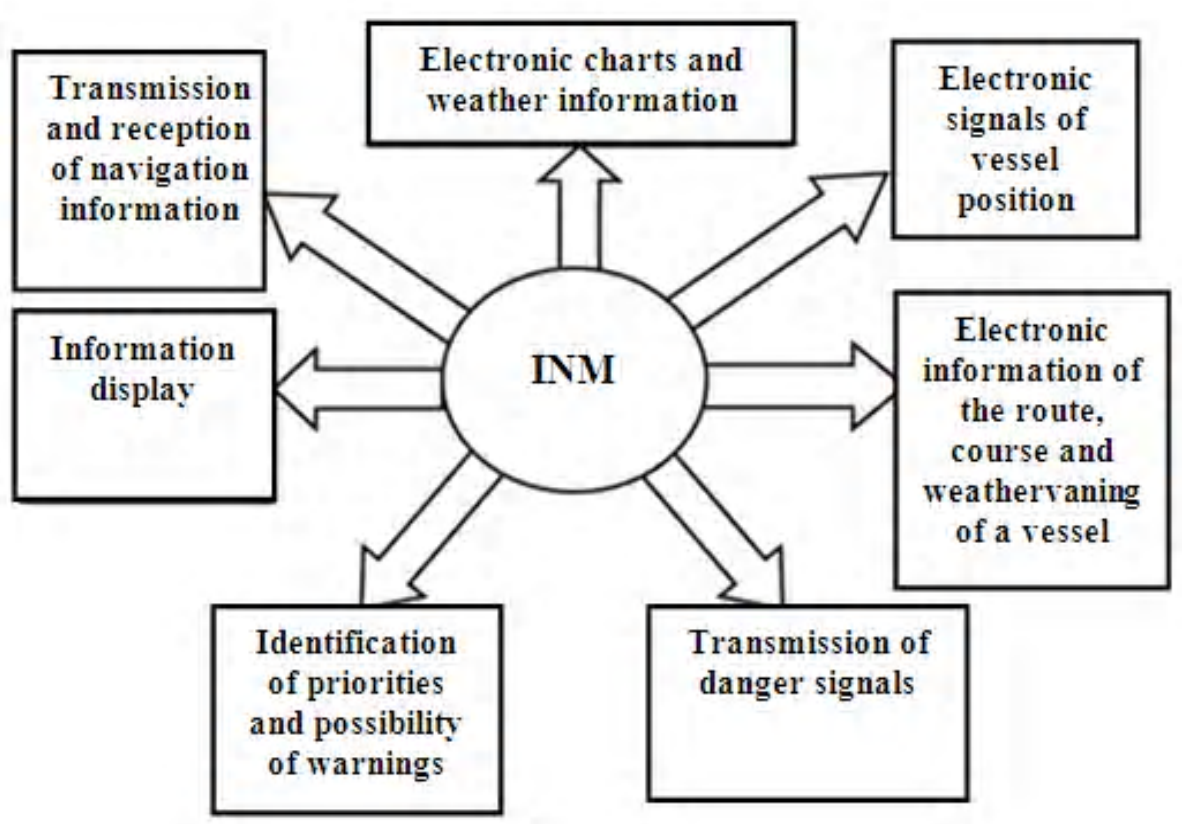

Figure 2 - Key components of the instrumental navigation method

- the real process of operation of navigation equipment system and equipment of coastal infrastructure should correspond to the calculated one;

- the stability of such a method is based on the analysis of a number of factors that are currently not taken into account due to the use of approximate models. It should be noted that the problem of determining the functional stability of such a complex organizational system remains open today.

The system should be optimized according to the set of criteria [8] characterizing the implementing of set tasks with the probability of safe navigation of water transport

$$
P_{\text {sm }}=1-\exp \left(D_{\min } / M\right)^{2} \geq 95 \% \text {. }
$$

Fig. 3 shows the layout of the system.

In our situation, the system for providing the navigation instrumental procedure is a complex entity, which is a set of interconnected elements. That is, an element is an indivisible part of the system that is independent. The indivisibility of the element is considered as inappropriate account of its internal structure within the framework of the model. The element itself is characterized only by its external manifestations in the form of links and interconnections with other elements. Plurality A of system elements can be described as [9]

$$
A=\left\{a_{i}\right\}, i=1, \ldots, n .
$$

Each element is characterized by specific properties $Z_{i 1}$, $\ldots, Z_{i m}$, which uniquely determine it in this system. The set of all properties $m$ of the element $a_{i}$ will be defined as the state of the element $Z_{i}$.

$$
\begin{gathered}
Z_{i}=\left(Z_{i 1}, Z_{i 2}, Z_{i 3}, \ldots, Z_{i \mathrm{k}}, \ldots, Z_{i m}\right) . \\
Q=\left\{q_{i j}\right\}, i, j=1, \ldots, n ., D=\{A, Q\}, \\
Z=\left(Z_{1}, Z_{2}, Z_{3}, \ldots, Z_{k}, \ldots, Z_{m}\right),
\end{gathered}
$$

Bilateral constraints cannot be greater than $n \&(n-1)$.
Possible states of such a real system form a certain set of admissible states of the system (subspace $Z_{\mathrm{CD}}$ ). The system has the properties of equilibrium, stability and is able to move from one state to another [10]

$$
Z\left(t_{1}\right) \rightarrow Z\left(t_{2}\right) \rightarrow Z\left(t_{3}\right) \ldots, Z(t)=[Z(t-1), y(t), x(t)] .
$$

Let us consider the dependencies of the state of the system on the functions of inputs and outputs.

$$
\begin{gathered}
\boldsymbol{X}=\left(x_{1}, x_{2}, x_{3}, \ldots, x_{k}, \ldots, x_{\mathrm{r}}\right) \Rightarrow Z(t)=F \mathrm{c}[\boldsymbol{X}(t)] \\
Z(t)=F \mathrm{c}[\boldsymbol{X}(t), Z(t-1), Z(t-2), \ldots] .
\end{gathered}
$$

Fig. 4 shows the feedback of individual elements of the system

$$
Y(t)=F_{\mathrm{B}}[\boldsymbol{X}(t)]
$$

For the $F_{\mathrm{B}}$ function, the real system has signs of static.

At the initial stage of the study, the object was studied with its further formalization. At this stage, a two-fold task appeared. On the one hand, this is the formalization of the object of the system research, on the other hand, the process of studying the system, the process of setting and solving the problem are formalized too. Features of the system:

1) the system depends not only on the functions of inputs $X(t)$, but also on the functions of states $\mathrm{Z}(t-1), \mathrm{Z}(t-2)$, that is, it has signs of the dynamical system

$$
Y(t)=F_{\mathrm{B}}[X(t), Z(t), Z(t-1), Z(t-2),(Z-v)] ;
$$

2) functioning of the system is carried out in a continuous mode

$$
\frac{d Z(t)}{d t}=F_{C}[X(t), Z(t)], \quad Y(t)=F_{B}[X(t), Z(t)] ; *
$$

3) $\forall Z_{\text {im }} \in Z \rightarrow Z_{\text {im }}=\neg Z, Z=Z_{1} \& Z_{2}$;

\begin{tabular}{|r|c|c|c|c|c|}
\hline$Z_{\text {im }}$ & $Z$ & $Z_{\text {im }}=\neg Z$ & $Z_{1}$ & $Z_{2}$ & $Z_{1} \& Z_{2}$ \\
\hline 0 & 0 & 0 & 0 & 0 & 0 \\
\hline 0 & 1 & 1 & 0 & 1 & 0 \\
\hline 1 & 1 & 0 & 1 & 0 & 0 \\
\hline 1 & 0 & 1 & 1 & 1 & 1 \\
\hline
\end{tabular}




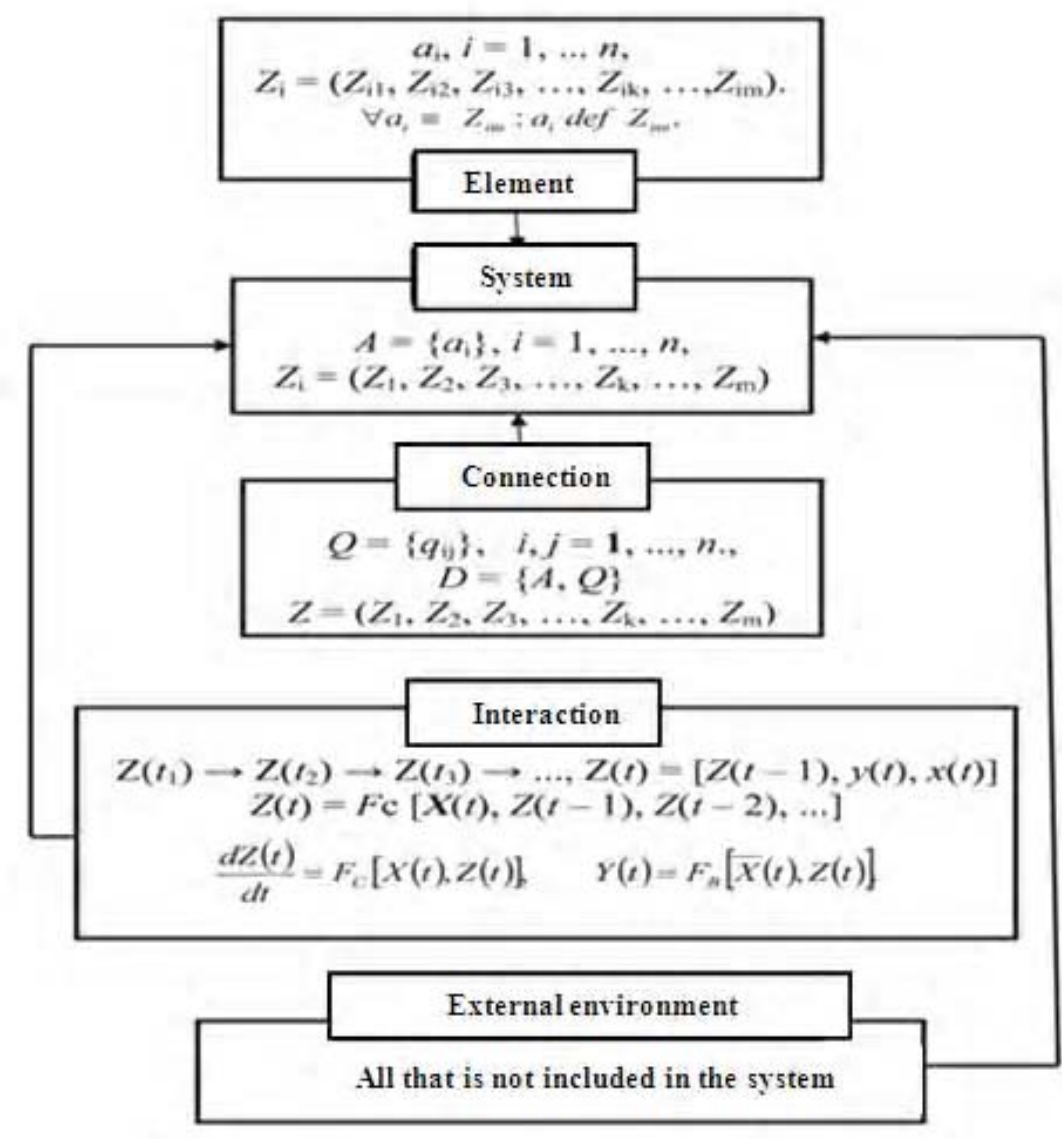

Figure 3 - The layout scheme of the system providing instrumental navigation method

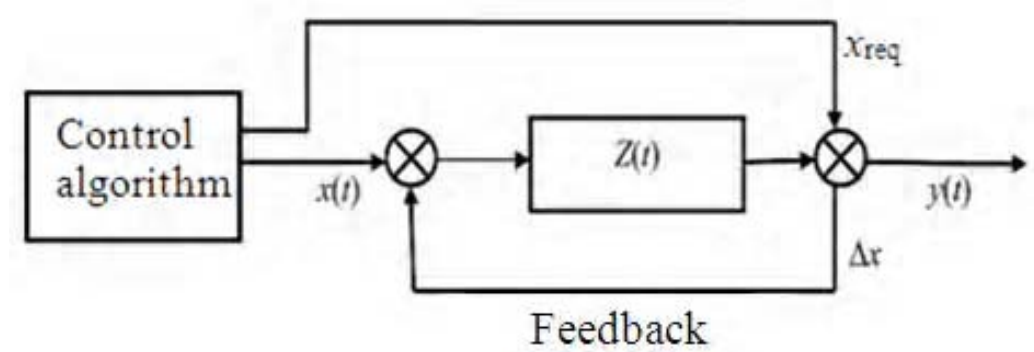

Figure 4 - Scheme of the subsystem with a single feedback

4) the system operates in conditions of significant uncertainty and effect of the environment, which causes the random nature of changes of its indicators

$p_{F}(x)=\sum_{i=1}^{n} p_{i}\left(x_{i}\right)=1, \int_{-\infty}^{\infty} p(x) d x=F(\infty)-F(-\infty)=1-0=1$;

5) the system carries out a purposeful selecting of its behavior. The functional stability of the system characterizes the deviation of the main functions from the display coordinates [11]

$$
\begin{aligned}
& \left.\forall E>0 \Rightarrow \Delta_{x, y}>0, V \mid f\left(x_{0}, y_{0}\right), f\left(x_{0}^{1}, y_{0}^{1}\right)\right]<\Delta_{x, y} \Rightarrow \\
& \Rightarrow V\left\{f(x, y)\left[t,\left(x_{0}, y_{0}\right)\right], f(x, y)\left[t,\left(x^{1}, y^{1}\right)\right]_{0}\right\}<E, \quad \forall t \in(o, \infty) .
\end{aligned}
$$

The stabilization process is characterized by the output from the domain of a given tube $W(t)$. The area $W(\tau)$ depends on $\tau=t_{2}-t_{1}$ the duration of the transient (Fig. 5). Instead of

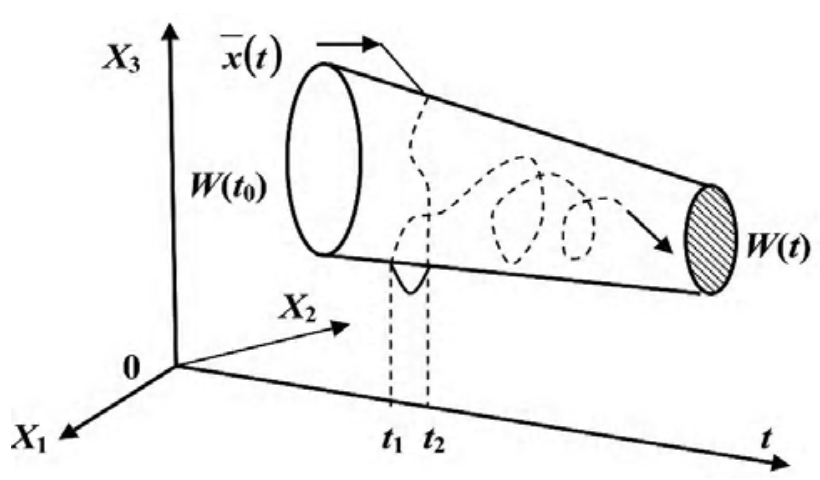

Figure 5 - Parameter variation of system parameters

inappropriate state of the system, the reaction in the form of a set of control influences $u(t)$ that belong to a set of hyperreal numbers $U^{*}$ is carried out and aimed at neutralizing the consequences in a minimum time $\tau$ : 
$\left\{\int_{(\Omega)} X\left(x_{1}, x_{2}, t_{2}\right) d \omega>W\left(t_{0}\right)\right\} \Rightarrow\left\{u(t) \in U^{*}[\delta[w(t), w(\tau)]]\right\}$.

The constituent

$\delta[w(t), w(\tau)]=\sup \{p[z, w(t) \cap w(\tau)], \quad z \in w(t) \cup w(\tau)\}$

characterizes the distance $p$ in the processes $\Omega(x, \tau, t) \in S$

$(\varepsilon)[w(t)]<\varepsilon$. Condition: $|t-\tau|<\gamma \Rightarrow \delta[\omega(\tau), \omega(\tau)]<\varepsilon$.

The processes of parameter stabilization are characterized as the stages of ensuring the functional stability of the corresponding subsystems, which work properly in the given intervals of variation of parameters.

An important task of this system analysis is the problem of decision making. The problem of decision making is connected with the choice of a certain alternative of the development of the system in a variety of uncertainties. With the use of modern mathematical apparatus it appeared impossible to rely only on strict mathematical methods. Therefore, informal procedures are widely used in system analysis: combination of formal and informal methods of analysis and synthesis.

Let's dwell on choosing the structure for the presentation of the system, taking into account its features and capabilities. The information estimates of the degree of wholeness $\alpha$ and the coefficient of the use of components of the $\beta$ system are used, which are interpreted as stability estimates when making structure elements independent. These estimates are received from the ratio that determines the relationship between the system, eigen and mutual complexity of this system [12]

$$
\left\{\begin{array}{l}
C_{C}=C_{0}+C_{B}, \\
\alpha=-\frac{C_{B}}{C_{0}}, \beta=\frac{C_{C}}{C_{0}}, \beta=1-\alpha .
\end{array}\right.
$$

The functional component of a multicomponent system is characterized by:

- its own complexity. In this case, $C_{\mathrm{o}}$ is the total complexity of system elements without connections between them (navigation tools, bridges, power lines, locks);

- the system complexity of $C_{c}$ characterizes the content of the system as a whole;

- the mutual complexity of $C_{\mathrm{B}}$ characterizes the degree of interconnection of the elements in the system;

- the estimate of $\alpha$ describes the stability and controllability of the system. A minus sign in the expression $\alpha$ is introduced for to be positive, since $C_{\mathrm{o}}>C_{\mathrm{c}}$;

- $\beta$ - coefficient describes the use of system elements.

We use a mathematical model in the form of a nonoriented graph due to logical connections in the system are two-sided. There are no loops and multiple edges in the graph. A set of vertices $V$ corresponds to a set of constituent elements of the power system $n$, and a set of edges $(E, F)$ corresponds to a set of functional connections between the constituent elements of the system. The specific state of this system characterizes $\langle v, e, f\rangle$ :

$$
G(V,\langle E, F\rangle), \quad V=\left\{v_{i}\right\},\langle E, F\rangle=\left\{\langle e, f\rangle_{i j}\right\}, i, j=1,2, \ldots n .
$$

$$
\begin{gathered}
v \subseteq V,|v| \leq|V|, \quad e \subseteq E, \quad|e| \leq|E|, \quad f \subseteq F,|f| \leq|F| . \\
\left|v^{+}\right|=|V| . \quad\left|e^{+}\right|=|E| . \quad\left|f^{+}\right|=|F| . \quad\left|v^{-}\right|<|V| . \\
\left|e^{-}\right|<|E| . \quad\left|f^{-}\right|<|F| .
\end{gathered}
$$

Signs of functional SZIMN stability are the connectivity of the graph $\{\mathrm{K}=1\}$ and the presence of bridges in its composition $N_{L} \geq 1$, as well as the loops of connection

$$
N_{V} \geq 1\{K=1\} \wedge\left\lfloor\left\{N_{V} \geq 1\right\} \vee\left\{N_{L} \geq 1\right\}\right\rfloor .
$$

It should be noted that (12) significantly reduces the functional stability of the divided information system, since all routes of information transmission from the vertices of one subgraph to the top of another will include this bridge or loop of convergence. Therefore, in order to bring the system into a functionally stable state, it is necessary to introduce reserve lines into the structure so that there are no bridges or junction loops in the structure. Several independent and alternative information transmission routes will appear.

The functional stability of the system is characterized by criteria [11] regarding the dimensions of the navigable channel $v_{1}^{-}<k_{1} \cdot V_{1}$; corner radius of the navigable channel on roll tacks $v_{2}^{-}<k_{2} \cdot V_{2}$; depth of the navigable channel $v_{3}^{-}<V_{3}-\Delta_{3}$; dimensions of the bridges $v_{6}^{-}<V_{6}-2 \cdot \Delta_{6}, \quad v_{6-1}^{-}<V_{6-1}-\Delta_{6-1}$; height of the wires of power lines $v_{7}^{-}<V_{7}-\Delta_{7}$; the accuracy of the vessel's coordinates $e_{1}^{-} \leq 10 \mathrm{M}$ (with a probability of 0.95 ); safe distances $v_{8}^{+}$, taking into account the edges in a non-oriented graph (12). Figure 6 shows the algorithm of system stability.

The developed method revealed the need to supply the system with a new inclusion element - an automated display of depths and isobaths for the actual water level on the electronic map. The application of the "black box" is a subsystem, which is isolated and connected to the external environment through a set of inputs $y_{1(t)}$ and outputs $y_{k(t)}$. Outputs of the "black box" model describe the performance of the subsystem, and inputs describe resources and constraints (Fig. 7):

$$
h(t)=\underbrace{\frac{1}{\operatorname{det}(p E-A)} S(p)}_{\text {const }} \cdot B+\underbrace{y_{01 B \Pi}+h_{10}}+\left\|\left(\delta y_{01 B \Pi}\right)_{i, 1}\right\| .
$$

The expression (13) is the result of intelligent processing of the data flow from water measuring points using symbolical and formalized Laplace transformations while navigating a vessel and it means a complete expression for obtaining differential corrections $h(t)$ of the depths indicated on the river electronic map. Thus, the uncertainty of situational dynamics in the $n$-dimensional space of vessel motion is eliminated. The conceptual model for obtaining differential corrections is depicted in Fig. 8. 


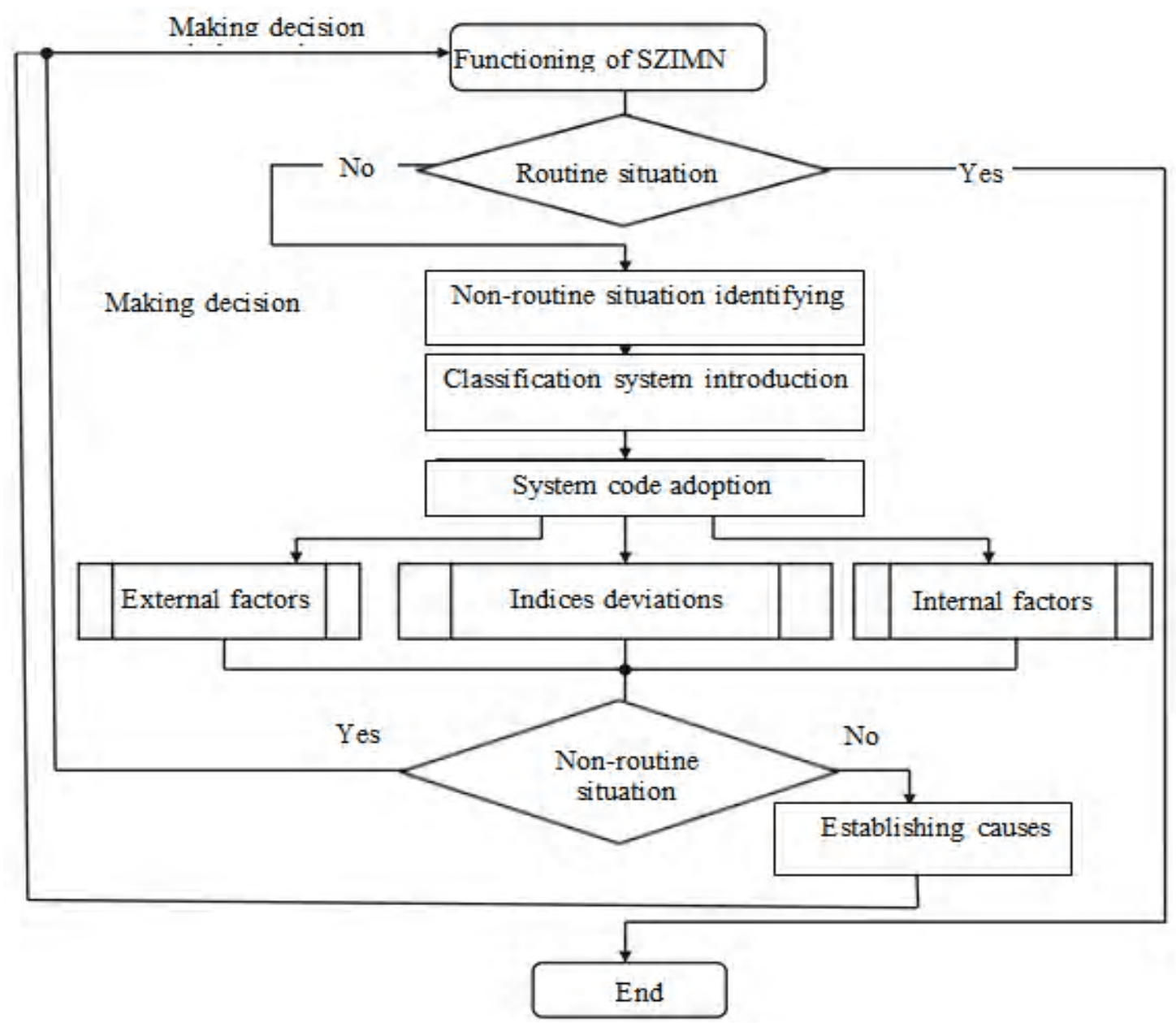

Figure 6 - Algorithm for the implementation of functional stability of the system

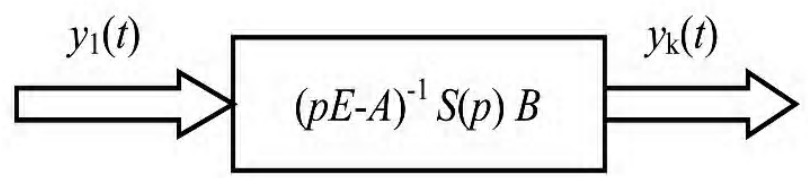

Figure 7 - Scalar transmission function of the subsystem of automated depth display

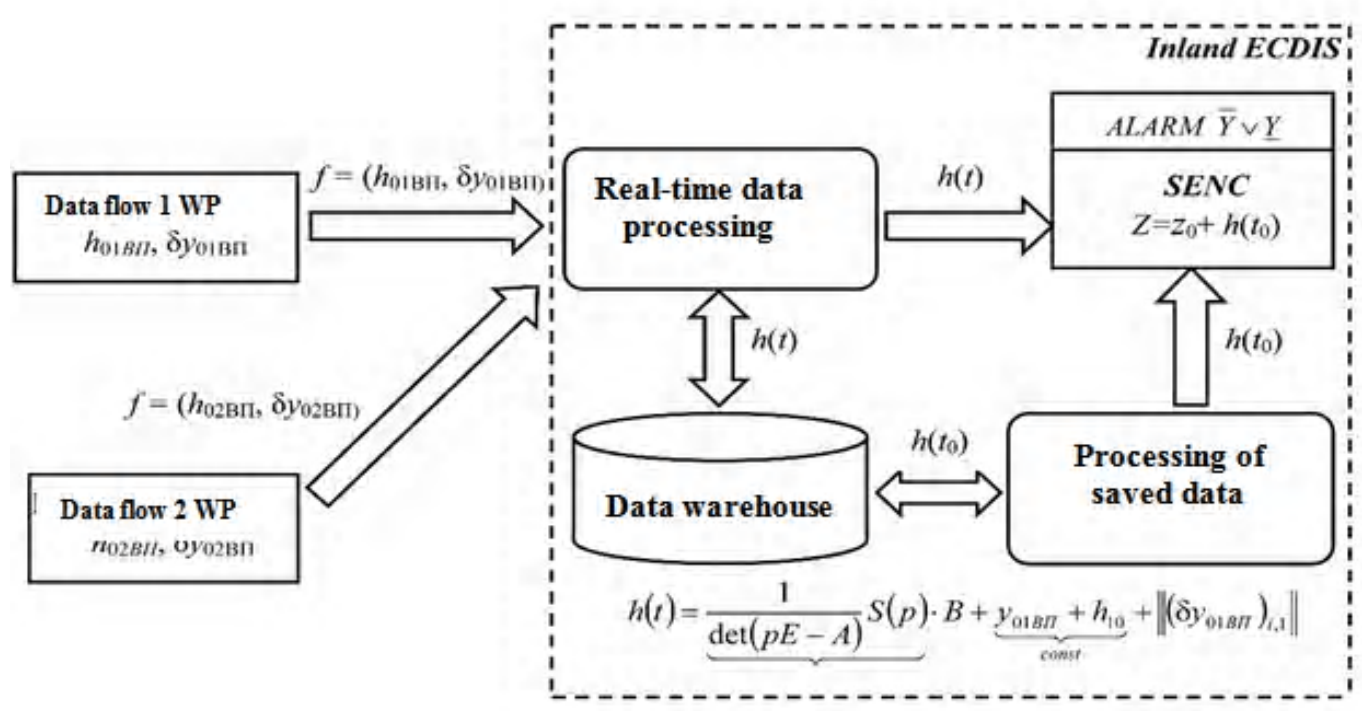

* BП - WP

Figure 8 - Conceptual model for obtaining differential corrections 


\section{EXPERIMENTS}

The developed technique enabled to consider the proposed system as two functionally interconnected components of subsystems $F_{1}$ and $F_{2}$ (river electronic chart system and coastal infrastructure). The result of the interaction of the two subsystems $F_{1}$ and $F_{2}$ is performing of the tasks with a probability of safe navigation $P_{\text {бп }} \geq 95 \%$ using expression (1) for specific conditions of water traffic. Besides this, the developed technique revealed the need to supply this system with a new inclusion element - an automated display of depths and isobaths for the actual water level on the river electronic map. Methods of collective generating of ideas and expert methods are used for its analysis.

Experimental studies of modeling of functioning process of the stages of functional stability of the coastal infrastructure and the studies of navigation equipment were carried out on the simulator of SeeMYENC River Electronic Chart System. Accordingly, when modeling the situation, certain elements of the system were set to nonoptimal values. In this case, the optimality of the system as a whole was determined. The calculation of the margin of stability with the capacity to be rebuilt in accordance with external conditions for the effective achievement of overall goal was carried out using the formulas $(1,11)$. The stability area in the vector space was calculated using the information from the river electronic maps. The fundamental point of modeling is that the removal of the consequences of non-routine situations was carried out by redistributing existing resources, including changing the mode of operation of the subsystems. Possible parameter variation was controlled within specified limits of the "operating tube" (Fig. 5). Observations obtained with this method were used to get a sample for solving the problem of ensuring the safety of water transport using expression (1). There is one fact of quitting the "tube" when positioning in the subsystem $F_{1}$.

\section{RESULTS}

The results of the experiments carried out are presented in table 1.

\section{DISCUSSION}

The existing visual (pilot) navigation method was not based on solving of tasks applying a scientific approach to the introduction of modern navigation system on inland waterways of Ukraine. Hence, the methods of system analysis were simple. Thus, the system analysis of the pilot navigation method was based on its consideration not as a system object, but as a simple sum of properties of the elements with the same type of multilevel communications [13]. This does not correspond to the regularities of complex object operation in a modern way of navigation through existing local, branch tasks and principles of ensuring its life cycle. The stability of functioning of the modern navigation method is based on the analysis of a number of factors that are currently not taken into account due to the use of approximate models [11]. It should be noted that the problem of determining the functional stability of such a complex organizational system as the system of providing the navigation instrumental procedure on inland waterways of Ukraine remains open today.

The article shows us a scientific approach to the introduction of a modern navigation system in the form of solving weakly structured problems, in the first instance, that are characterized by the presence of uncertainty factor and contain both formalized and non-formalized elements; the article also used information estimates of the degree of wholeness and the coefficient of use of components of the system, which are interpreted as stability estimates when making structure elements independent. Thus, combining of information from numerous sources takes place, in order to find more accurate and reliable data about the situation than the results obtained from these sources separately.

The proposed method of system analysis provides greater accuracy of forecasting, eliminates significant ambiguity, vagueness and unpredictability of situations of extreme, risky nature. Thus, the theoretical incompleteness and multi-valued possibility of various interpretations in practice leads to dangerous statistics of disasters, accidents, unwanted events with passengers, crews, cargos, as well as contamination of the ecological system [10]. However, the proposed method requires more time spent on sampling than the method of system analysis for the visual (pilot) navigation method, and the success / effectiveness of its application depends on its requirements for computing resources. Subject, theme, task of introducing the proposed method will be more understandable when recording the full description of the whole object using single language in the form of

$$
\left\{A=\left\{a_{i}\right\}_{i=\overline{1, n}}, Z=\left\{z_{i j}\right\}_{i-\overline{1, n} ; j=\overline{i, m}}, Q=\left\{q_{i j k}\right\}_{i=\overline{1, n} ; j=\overline{1, m} ; k=\overline{1, l}}\right\}
$$

\section{CONCLUSIONS}

The task of applying the scientific approach to the implementation of the modern navigation system on inland waterways of Ukraine on the basis of the river electronic cartographic systems is solved in the paper. The most important stage in the implementation of the modern navigation system is the complex implementation of the system analysis of the problem situation, taking into account the specific character of water transport traffic. In the process of research during the process of system analysis, a set of

Table 1 - Experiment results

\begin{tabular}{|c|c|c|c|c|c|c|c|}
\hline ENC & $\alpha(11)$ & $\beta(11)$ & $\delta y(12), m$ & $h(t)(12), m$ & $\Delta_{3}, m$ & $P_{\text {sm }}(1), \%$ & Дата, час $t$ \\
\hline UA7N007.000 & 0,79 & 0,21 & 0,2 & 4.6 & 3,2 & 0,97 & $24.07 .2017,10-00$ \\
\hline UA8N0028.000 & 0,73 & 0,27 & 0 & 5,2 & 3,2 & 0,96 & $25.07 .2017,19-00$ \\
\hline UA8N0082.000 & 0,67 & 0,33 & 0,2 & 5,4 & 3,6 & 0,96 & $27.07 .2017,11-00$ \\
\hline UA7N0036.000 & 0,80 & 0,29 & 0,1 & 6,2 & 3,6 & 0,97 & $28.07 .2017,17-00$ \\
\hline
\end{tabular}


procedures with elements of scientific novelty was used: the definition of an overall aim, the recommendation of a set of alternatives to achieve these aims, which are compared to some or other performance criteria. result of decomposition, when applying the proposed system analysis, new elements and subsystems were first justified and implemented: such as the functional stability of the navigation system (estimates, signs, criteria) with a set of permissible states, the automated display of real depths on the system electronic card.

The practical significance of the obtained results is that the introduction of the proposed method will enable refusal of the installation of coastal and floating means of navigation equipment, will provide differentiated mapping of depths on the electronic map, depending on an actual water level, and refuse the pilot principle of navigation on the inland waterways of Ukraine. In addition, it should be noted that the introduction of the navigation instrumental procedure will enable to quickly shut down navigation on the fairway channels in particular periods and follow only selected vessels.

Prospects for further research. It should be noted that the final conclusion about the correctness of the system analysis of such a complex system can only be made on the basis of the results of its practical application. The final result will depend not only on how thorough and theoretically grounded the methods used in the analysis are, but also on how accurately and qualitatively the received recommendations are realized. It should also be borne in conducted and then their results are put into practice, happens relatively rare in practice, and it is only in those cases when it comes to relatively simple systems. In the study of such a complex system, it varies over time, both by itself and under the influence of researches. That is, the problem is gradually solved in the course of an active research.

\section{ACKNOWLEDGEMENT}

The work was carried out within the scope of the research theme "Methods of ensuring the safety of water transport electronic-mapping systems", which is approved by the decision of the Scientific Council of the State University of Infrastructure and Technologies (registration number ID: 64940 27.08.2016(398-1)).
The scientific novelty of the obtained results is that as a mind that the situation, where researches are initially with the use of the detailed depicting of depths in river

\section{REFERENCES}

1. Вагущенко Л. Л. Современные информационные технологии в судовождении: учебное пособие / Л. Л. Вагущенко. - Одесса : OHMA, 2013. - $135 \mathrm{c}$.

2. Машков О. А. Розвиток теорії функціональної стійкості, як стійкості функціонала якості складної системи / О. А. Машков, В. Р. Косенко. - Інтелектуальні системи прийняття рішень $\mathrm{i}$ проблеми обчислювального інтелекту : Міжнародна наукова конференція ISDMCI'2016, Херсон, 24-28 травня 2016 р. : матеріали конференції. - Херсон: Видавництво ПП Вишемирський В. С., 2016. - С. 93-104.

3. Барабаш О. В. Функціональна стійкість - властивість складних технічних систем / О. В. Барабаш, Ю. В. Кравченко // Збірник наукових праць НАОУ. - 2002. - Бюл. № 40. - С. 225-229.

4. Вагущенко Л. Л. Судовые навигационно-информационные системы: учебное пособие / Л. Л. Вагущенко. - Одесса : OHMA, 2004. - 302 c.

5. Гагарский Д. А. Электронные картографические системы в современном судовождении: учебное пособие / Д. А. Гагарский. - Санкт-Петербург: ГМА имени адмирала Макарова, 2007. $-61 \mathrm{c}$.

6. Анохин П. К. Избранные труды: философские аспекты теории систем : монография / П. К. Анохин. - Москва : «Наука», 1978.- $190 \mathrm{c}$.

7. Берталанфи Л. Фон. Общая теория систем: критический обзор : монография / Берталанфи Л. Фон. - Москва : «Прогресс», 1969. $-82 \mathrm{c}$.

8. Доронін В. В. Системна технологія розв'язку оперативних задач навігації для синтезу законів експлуатації водного транспорту / В. В. Доронін. - Харків : Системи обробки інформації. - 2015. - № 10 (135). - С. 186 - 191.

9. Бронштейн И. Н. Справочник по математике: коллективная монография / И. Н. Бронштейн, К. А. Семендяев. - Москва : «Наука», 1980. - 974 с.

10. Панін В. В. Структурне моделювання та символьні перетворення для управління рухом транспортних засобів: колективна монографія / [В. В. Панін, Г. Л. Баранов, А. М. Носовський и др.]. - Київ : МОН України, 2014. -310 с.

11. Doronin V. V. Application of evaluation criteria of functional sustainability instrumental method of navigation on Ukraine's inland water ways / V. V. Doronin, M. V. Aleinikov, V. M. Aleinikov // Intellectual Systems for Decision Making and Problems of Computational Intelligence: XIII International Scientific Conference (ISDMCI'2017). - Kherson: PP Vyshemyrskyi V. S., 2017. - P. 179-180.

12. Волкова В. Н. Системный анализ и его применение в АСУ : коллективная монография / В. Н. Волкова, А. А. Денисов. Ленинград : ЛПИ, 1983. -83 с.

13. Симоненко С. В. Навігаційне забезпечення мореплавства: виробнично-практичний посібник / С. В. Симоненко, М. Ф. Голодов. - Київ : ДУ «Держгідрографія», 2014. - 264 с.

Article was submitted 12.09.2017. After revision 25.11.2017.

Панін В. В. ${ }^{1}$, Доронін В. В. ${ }^{2}$, Алейніков В. М. ${ }^{3}$

${ }^{1}$ Д-р техн. наук, професор, ректор, Державний університет інфраструктури та технологій, Київ, Україна

${ }^{2}$ Канд. техн. наук, професор кафедри Технічних систем і процесів управління в судноводінні, Державний університет інфраструктури та технологій, Київ, Україна

${ }^{3}$ Аспірант, Державний університет інфраструктури та технологій, Київ, Україна

ЗАСТОСУВАННЯ СИСТЕМНОГО АНАЛІЗУ ВПРОВАДЖЕННЯ ІНСТРУМЕНТАЛЬНОГО МЕТОДУ НАВІГАЦІЇ НА ВНУТРІШНІХ ВОДНИХ ШЛЯХАХ УКРАЇНИ

Актуальність. Вирішено завдання застосування наукового підходу щодо впровадження сучасної системи навігації на внутрішніх водних шляхах України у вигляді вирішення в першу чергу слабоструктурованих проблем, що характеризуються наявністю фактора невизначеності і містять як формалізовані, так і неформалізовані елементи, що не перекладаються на мову математики.

Мета роботи - розробка методики системного аналізу на етапі впровадження інструментального методу навігації на внутрішніх водних шляхах України, яка гарантує високу якість моделювання згідно з точнісними критеріями судноплавства і економічності. 
Метод. Запропонований підхід до обробки даних, який заснований на вивченні властивостей системи 3 подальшою їі формалізацією. Розроблена модель компонування системи на базі електронно-картографічних систем, що характеризує виконання поставлених завдань $з$ підвищеною ймовірністю безпечного плавання. Розглянуто особливості стану системи з використанням математичної моделі у вигляді неорієнтованого графа. Запропонований алгоритм реалізації функціональної стійкості системи. Результати експериментів дозволяють рекомендувати запропонований метод для впровадження інструментального методу навігації на внутрішніх водних шляхах України.

Результати. Відпрацьовані показники експериментальних досліджень процесу функціонування етапів функціональної стійкості берегової інфраструктури і суднового навігаційного обладнання.

Висновки. У процесі дослідження використаний комплекс процедур, що мають елементи наукової новизни і спрямовані на формулювання проблемної ситуації, висунення множини альтернатив, які зіставляються 3 критеріями ефективності із застосуванням коефіцієнтів стійкості системи.

Ключові слова: безпека руху, електронно-картографічна система, інструментальний метод навігації, алгоритм, багатопараметрична оптимізація, граф, лінгвістичний аналіз, моделювання.

Панин В. В. ${ }^{1}$, Доронин В. В. ${ }^{2}$, Алейников В. М. ${ }^{3}$

${ }^{1}$ Д-р техн. наук, профессор, ректор, Государственный университет инфраструктуры и технологий, Киев, Украина

${ }^{2}$ Канд. техн. наук, профессор кафедры Технических систем и процессов управления в судовождении, Государственный университет инфраструктуры и технологий, Киев, Украина

${ }^{3}$ Аспирант, Государственный университет инфраструктуры и технологий, Киев, Украина

ПРИМЕНЕНИЕ СИСТЕМНОГО АНАЛИЗА ВНЕДРЕНИЯ ИНСТРУМЕНТАЛЬНОГО МЕТОДА НАВИГАЦИИ НА ВНУТРЕННИХ ВОДНЫХ ПУТЯХ УКРАИНЫ

Актуальность. Решена задача применения научного подхода по внедрению современной системы навигации на внутренних водных путях Украины в виде решения в первую очередь слабоструктурированных проблем, характеризующихся наличием фактора неопределенности и содержащих как формализованные, так и неформализованные элементы, которые не переводятся на язык математики.

Цель работы - разработка методики системного анализа на этапе внедрения инструментального метода навигации на внутренних водных путях Украины, гарантирующей высокое качество моделирования согласно точностных критериев судоходства и экономичности.

Метод. Предложен подход к обработке данных, который основан на изучении свойств системы с дальнейшей ее формализацией. Разработана модель компоновки системы на базе электронно-картографических средств, которая характеризует выполнение поставленных задач с повышенной вероятностью безопасного плавания. Рассмотрены особенности состояния системы с использованием математической модели в виде неориентированного графа. Предложен алгоритм реализации функциональной стойкости системы. Результаты экспериментов позволяют рекомендовать предложенный метод для внедрения инструментального метода навигации на внутренних водных путях Украины.

Результаты. Отработаны показатели экспериментального исследования процесса функционирования этапов функциональной стойкости береговой инфраструктуры и судового навигационного оборудования.

Выводы. В процессе исследования использован комплекс процедур, которые содержат элементы научной новизны и направлены на формулирование проблемной ситуации, выдвижение множества альтернатив, которые сопоставляются с критериями эффективности с применением коэффициентов стойкости системы.

Ключевые слова: безопасность движения, электронно-картографическая система, инструментальный метод навигации, алгоритм, многопараметрическая оптимизация, граф, лингвистический анализ, моделирование.

\section{REFERENCES}

1. Vahushchenko L. L. Modern Information Technologies in Navigation: Textbook. Odessa, ONMA, 2013, P. 135.

2. Mashkov O. A., Kosenko V. R. Development of the theory of functional stability as a stability of the functional quality of a complex system, Intelligent decision making and intelligent computing problems: International Scientific Conference ISDMCI'2016, Kherson, May 24-28, 2016: Conference materials. Kherson, Publishing house PE Vyshemyrskyi V.S., 2016, P. 93-104.

3. Barabash O. V., Kravchenko Yu. V. Functional stability - the property of complex technical systems, Collection of scientific works of NAOU, 2002, Bull. No. 40, P. 225-229.

4. Vagushchenko L. L. Ship navigation and information systems, Textbook. Odessa, NAOU, 2004, P. 302.

5. Haharski D. A. Electronic cartographic systems in modern navigation : Textbook. St. Petersburg, HMA named after Admiral Makarov, 2007, P. 61.

6. Anokhin P. K. Selected Works: Philosophical Aspects of Systems Theory : Monograph. Moscow, Science, 1978, P. 190.

7. Bertalanfi L. Von. General theory of systems: a critical review: monograph. Moscow, "Progress", 1969, P. 82.
8. Doronin V. V. Systemic technology of the solution of operational tasks of navigation for the synthesis of the laws of operation of water transport. Kharkiv, Systems of information processing, 2015, No. 10 (135), P. 186-191.

9. Bronstein I. N., Semendiaiev K. A. Reference book on math: a collective monograph. Moscow, "Science", 1980, P. 974.

10. Panin V. V., Baranov G. L., Nosovskyi A. M., Tykhonov I. V. Vasko S. M. Structural modeling and symbolic transformations for controlling the motion of vehicles: a collective monograph. Kyiv, MES of Ukraine, 2014, P. 310.

11. Doronin V. V., Aleinikov M. V, Aleinikov V. M. Application of Evaluation Criteria for Functional Sustainability in Ukraine Inland Waterways, Intellectual Systems for Decision Making and Problems of Computational Intelligence: XIII International Scientific Conference (ISDMCI'2017), Kherson, PP Vyshemyrskyi V. S., 2017, P. 179-180.

12. Volkova V. N., Denysov A. A. System analysis and its application in the automated control system: a collective monograph. Leningrad, LPI, 1983, P. 83.

13. Symonenko S. V., Holodov M. F.- Navigation equipment: production and practical textbook. Kyiv, GA "Derzhhidrographia", 2014, P. 264. 